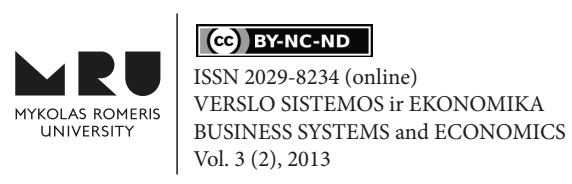

\title{
FEMALE ENTREPRENEURSHIP PATTERNS: A THEORETICAL COMPARATIVE STUDY
}

\author{
Xenia ANDRIUTA \\ Academy of Economic Studies of Moldova \\ Faculty of Finance \\ str. Banulescu-Bodoni, 59; MD-2005 Chisinau, Republica Moldova \\ E-mail: andriuta_xenia@yahoo.com \\ Jekaterina KARTAŠOVA \\ Mykolas Romeris University \\ Faculty of Economics and Financial Management \\ Ateities str. 20, LT-08303 Vilnius, Lithuania \\ E-mail: jkartasova@gmail.com \\ doi:10.13165/VSE-13-3-2-05
}

\begin{abstract}
The paper aims to bring to the light the importance of female entrepreneurship by providing a theoretical research of studies held in the field of female entrepreneurship. The main focus of the paper is to demonstrate the difference in motivation, performance and barrier patterns for female start-ups according to geo-economic conditions, as female entrepreneurship conditions are different in countries with strong economies and in countries with less developed economies. Several case studies are analyzed in order to compare performance of female entrepreneurship in different countries. Finally, a comparative analysis of data is performed and the authors conclude upon female entrepreneurship patterns identified in different countries and suggest promoting female entrepreneurship.
\end{abstract}

Keywords: entrepreneurship, women, development, promotion.

JEL classification: M13, J16.

\section{Introduction}

Female entrepreneurship, as a topic of academic research, has attracted considerable attention from scholars, practitioners and governments during the last years. The recognition of the fact that women make an important contribution to national economies in terms of job creation, economic growth and wealth generation has been expanding lately (Macaulay, 2003; Prowess Report, 2005; Centre of Women's Business Research, 2005). There are around ten million self-employed women in Europe, while women owned firms make up between a quarter and a third of the business population 
worldwide (NFWBO, 1997; OECD, 2004). Women are starting the so called "new economy companies", mastering in providing high-quality services, managing enterprises within life sciences and high technologies sectors (Carlassare, 2000). Women also provide innovative answers to problems of managerial, administrative and relation matters.

Despite these recognized merits, the condition of female entrepreneurship is still far behind the male ones. This paper seeks to answer what impedes women from starting-up their own businesses, analyzes the resources available and constraints encountered. Secondly, the paper outlines the performance and growth of female-owned enterprises. Thirdly, to go deeper into the empirical evidence, the authors analyze data of several case studies around the world, concerning female entrepreneurship activity. The main objective of this paper is to prove that the analyzed patterns, such as motivation, obstacles faced, etc., in female entrepreneurship depend on their geo-economic condition. Facing this challenge, the authors bring several examples from transition, developing and developed countries to illustrate the scientific viability and importance of the above-stated objective. Fourthly, the comparative analysis of case studies is performed, outlining the main issues discussed. Finally, the paper concludes that the level of the development of the country (where female entrepreneur start-ups are situated) is tightly linked to and exercises a high level of influence on the above-mentioned patterns, especially on the motivational factor of start-ups. The level of the research is descriptive and comparative and deals with previously held researches in order to highlight the differences between business start-up conditions in different countries.

\section{Comparative analytical study of female entrepreneurship}

Female owned enterprises can be differentiated among themselves. The main criterion, which is going to be used to differentiate them, is how geo-economical conditions motivate women to start up a business venture. Recent evidence has proved that the rate of female entrepreneurship tends to be relatively higher in developing countries than in developed ones (Minniti et al, 2006). It is believed that women face more impediments in developing countries, when getting employed in the formal labour sector, and find themselves forced to become self employed as a way to overcome unemployment and poverty. In the process of entrepreneurship in transition economies, women have been designated with a particular function not only because they should take advantage from the entrepreneurship as the underprivileged and the discriminated, but also because of their crucial role in the household and increase in female-headed households across the developing world (Horrell and Krishnan, 2007). Another important detail that has to be pointed out is the belief that female-led micro- and small enterprises (MSEs) can have a substantial influence on overall household welfare and consumption, compared to male-led MSEs. It has been observed that female entrepreneurs and managers of households have the tendency to invest more in household health, nutrition and education than men and are disposed to employ pro rata more females than male-managed ventures (Nichter and Goldmark, 2009).

Taking into consideration these reasons, encouraging, enlarging and spreading out female entrepreneurship has become a worthwhile objective not only to empower women (Fafchamps and Quisumbing, 2005), but also to diminish poverty in emerging countries (Anderson and Eswaran, 2009). To illustrate the empirical side of the matter, the authors provide several case studies from transitional and developed economies. 


\section{Case study of female entrepreneurship in transition country: knitwear factory in Moldova}

In 1994, Janna and her husband Petru founded a small family knitwear factory enterprise in the capital of Moldova. Its main activities are sewing and selling clothes.

The motivation for this start-up was the loss of their jobs, which can be classified as a push reason.

Initially, both contributed equally to the business. As the venture was growing, more management duties were performed by Janna. In 1990, Janna became the general manager of the enterprise.

At the moment of performing the case study, 78 persons were working at the factory. According to Moldovan legislation, the venture is classified as a medium-sized enterprise. However, the manager is willing to maintain long-term business contracts with employees that she trusts rather than expand her business activity. From her perspective, state authorities are not trustworthy. This lack of institutional trust can be classified as a barrier hindering this particular case of female entrepreneurship from excelling, as well as many other businesses in transition contexts.

The knitwear factory serves mainly the Moldavian market, with a substantial part of the produced items being sold in the regions. Promotion tools used are preferential terms (delay of payment) offered to some retailers and taking part in the majority of regional trade fairs.

Janna's entrepreneurial skills have been demonstrated by quickly recognizing opportunities to export. She has made business with a retailer in Israel and has had business collaborations with retailers from states such as the Ukraine, Russia, and Romania.

Analyzing the success pattern, the fact can be mentioned that since 1994 the business has been constantly developing: sales and profits have grown, the equipment has been modernized and new jobs have been created. Janna's strategy can be described as growth-oriented. However, the hostile business environment in Moldova hinders her from realizing her ambitions. The next three paragraphs refer to the barriers that keep the business away from growing.

First, the owner has mentioned the unstable economic system in Moldova. This also includes legislation, situation on foreign markets, etc. Entrepreneurs have to keep track of the recurrent modifications in regulations and ever-changing business policies. The businesswoman has also pointed out that in this unfavourable environment bribing public officials rather than following the (changed) rules has become a way of making business.

The second hardship mentioned by Janna is connected to the growth of the business. Criminal organizations are likely to become interested in firms that have big turnovers. In case her business expanded, she would probably find herself forced to sell it or the business would just be taken over.

Another problem faced by the owner concerns the availability of skilled labor, first, because of the fact that her searching is confided to her friends circle and secondly due to the fact that workers trained in Soviet times have retired, emigrated or lost their skills as a result of unemployment, and lately very few people have been receiving education as professional workers.

Taking into account the example of Janna's knitwear factory, it can be concluded that it is showing considerable entrepreneurial spirit and alertness, illustrating a viable and successful female owned business case in contemporary Moldova, despite the faced government barriers and hostile business climate. 
The business shares multiple common features, which are also visible in mature market economies, complemented by distinguishing elements that help the business to succeed in a transition context.

Next, the comparison of the situation of female entrepreneurship in the transitional economies of Lithuania and the Ukraine is presented in order to outline the key patterns found.

\section{Case study of female entrepreneurship in developing economies: Lithuania and the Ukraine}

This case study compares two countries at different stages in the process of transformation. Lithuania found a rapid path leading to the EU membership, while the Ukraine is following a much slower transitional path. A parallel between these two economies will be drawn in order to identify common and distinctive features in terms of motivation, barriers faced and successes of female entrepreneurs.

Empirical data from two surveys have been used to compare the features of female entrepreneurship, comprising their motives for starting-up, enterprises' performance and obstacles faced.

Lithuanian results showed that most women entrepreneurs were aged between 40 and 49 years, while in the Ukraine women less than 30 years old were more likely to run their own business. Taking into account the fact that the reported figures represent entrepreneurs' age at the time of the survey rather than their age at the start up, the evidence suggests that entrepreneurship is considered as an employment or career option by younger women in the Ukraine.

In both surveys, women entrepreneurs were asked to explain why they decided to start their own businesses. The results showed that the most of the respondents were motivated by intrinsic goals, such as being independent. Qualitative evidence from the case studies suggests that it was "independence" in the sense of doing something for themselves rather than relying on others, combined with a desire to have more control over their own destiny. The responses from Lithuanian women showed slightly different results. Equal percentages of female SME owners were motivated not only by pull factors, such as the "desire to have their own business" and the "challenge" of having a private business, but also by push factors, such as "economic reasons" and "unemployment". The comparison of female entrepreneurs in Lithuania and the Ukraine seems to indicate that even in more advanced transition environments, such as Lithuania, "necessity" and push factors remain important drivers for women entrepreneurs at the start-up.

In the Ukrainian study, the methods used to assess business performance involved asking the respondents about the relationship between income (revenues) and expenditure (costs) for their enterprises during the previous 12 months. In the Lithuanian survey, the respondents were asked to classify their earnings in terms of their ability to cover their living expenses with four options available, ranging from "more than sufficient" and "sufficient" to "not sufficient" and "completely insufficient". The results showed that only a minority of women-owned businesses in either country appeared to be generating an excess surplus over the costs of their operations, which is a significantly worse pattern of performance than in the case of their male-owned counterparts. There were some interesting differences, as well. The results gained from the Lithuanian respondents were especially worrisome since the majority of female SME owners reported making insufficient earnings to cover their living expenses, 
suggesting that many of these enterprises were operating close to the edge of economic viability. In the Ukraine, although the reported performance of women-owned enterprises was significantly better than in Lithuania, it was in the majority of cases worse than that of their male-owned counterparts; little more than a quarter were clearly profitable.

The respondents were also asked to identify three main barriers they faced in running their businesses, in an order of importance. In the Ukraine, women entrepreneurs identified taxation as the most important barrier. The second most commonly reported obstacle was regulatory and legal issues. The respondents from the Ukraine were also more likely to identify financial constraints, reflecting greater pressure on cash flow, associated with their weaker financial performance in the previous financial year, as well as possibly greater under-capitalization at the start-up and less ability to raise external finance.

In Lithuania, the biggest barrier to the business development identified by the female entrepreneurs was taxation, followed by "low purchasing power". The third most important barrier chosen by the female entrepreneurs was lack of financing for business investment. To reach a full understanding of the differences in female entrepreneurship patterns, another case study is provided, which outlines the reasons for starting-up, the problems faced and the success factors.

\section{Case study of female entrepreneurship in developed economy: Canada}

This case study is based on the results of a questionnaire used by Benzing, Chu and Kara (2009). It was used for interviewing female entrepreneurs on three key factors regarding their activity: motivation, success and barriers. Respondents were proposed to evaluate their situations not only by a given scale, but also they had the opportunity of adding a further item to the Motivations and Barriers scales, should they believe their own situation had not been entirely covered by the pre-determined items in that scale.

Using telephone interviews, a total of 636 female-owned businesses from the 5580 entrepreneurial establishments (excluding professional services such as dentists, lawyers, physicians) from a list of InfoCanada were contacted. 476 businesses out of the 636 businesses contacted were either closed or not reachable, whereas 54 businesses out of the 160 businesses in the sample answered the survey, which constitutes a $33.75 \%$ response rate. Respondents were contacted by telephone over a period of one month in May and June, 2009. These entrepreneurial firms consisted of small and medium-sized companies.

Consistently with the literature on female entrepreneurship, a large proportion of the sample was involved in the retail and service sectors (94\%). The main products and services offered were food, beverages, accommodations, clothes, general merchandise, advertising, bookkeeping, design and pet services.

Regarding the involvement of their families in their business, 21 respondents (38\%) had a spouse actively involved, and 11 (20\%) had one or more children actively working within the business. While the respondents spent 48.8 hours on average per week working in their business, spouses spent an average of 31.2 hours, while children worked 29.6 hours on average per week with them.

The question on motivations required the respondents to rate the importance of each objective on a five-point scale with one (1) being "unimportant" to five (5) being "extremely important". 
Based on survey responses, the primary reasons for owning their own business were "for my own satisfaction and growth" (4.29), "to have fun" (3.92), "to prove they can do it" (3.79) and "to be my own boss" (3.74), while the variables "to build a business to pass on" (2.29), "to provide job for family members" (2.40) and "to gain public recognition" (2.64) received relatively less priority.

The question about success factors required the respondents to rate the importance of each factor on a five-point scale with one (1) being "unimportant" to five (5) being "extremely important". The most important business success variables were "reputation for honesty" (4.96) and "good customer service" (4.91), "hard work" (4.81) and "friendliness to customers" (4.78). Success factors mentioned as the least important by the respondents were "satisfactory government support" (2.19) and "political involvement" (1.64). It is noteworthy to mention that the success factor "access to capital" was not considered important by the respondents, which can be explained by the fact that most of the respondents did not use much external financing.

The three most serious problems faced by female entrepreneurs in Sudbury were a "weak economy" (3.33), followed closely by a "high business tax" (3.31) and the "unavailability of skilled labour" (3.30). Obtaining financing was also a problem raised by the respondents, since the two variables related to capital came in fifth and sixth places. The least important obstacles mentioned by the respondents were "foreign exchange limitations" (1.75) and "electricity/power supply problems" (2.10), which is not surprising, as their businesses were selling local services only in an area, where power supply is rarely disrupted.

\section{Comparative analysis of the analysed case studies}

The data used has been drawn from different studies and surveys, implicitly the questions asked were typically not the same. Although this makes a direct statistical comparison inappropriate, it is still possible to analyze the figures emerging from the data provided. The results could face critics because of the comparison of one particular business case from Moldova with statistical evidence from the Ukraine, Lithuania and Canada. However, it is assumed that the business case from Moldova is a representative one for the economy and describes in a realistic way business climate for female entrepreneurs. Nevertheless, it cannot be stated that it provides complex evidence on the situation in all post-soviet transition economies. This is the reason, why the cases of Lithuania and the Ukraine were also considered. Along with some differences found, the similarities in motivation for female start-ups, problems and barriers experienced and also the business environment for the three analyzed transition economies were identified. This fact makes possible to draw conclusions not only about economic mentality of female entrepreneurs in post soviet space, but also about similar economic conditions, as the motivation factors, which contributed to the start-ups, are showing resemblance. Mostly, the women were motivated to set up business as a career opportunity (considering both pull and push factors). Nevertheless, the case of Moldova presented the reason for job losses. The results of the Ukraine showed a bigger desire for "independence" among women, while the Lithuanian case showed that female SME owners were motivated not only by pull factors, such as the "desire to have their own business" and the "challenge" of having a private business, but also by push factors, such as "economic reasons" and "unemployment". Looking upon the Canadian case study, the main 
reasons identified for the starting-up were "for my own satisfaction and growth", "to have fun", "to prove they can do it" and "to be my own boss". According to these results, it can be concluded that there is a big gap between reasons for women owning a business in a developed economy and women who establish business in transition economies. In a developed economy (the case of Canada) women are mostly motivated by intrinsic factors, while in developing countries women entrepreneurs are most likely to be driven by necessity.

Assessment of female owned businesses performance in transition countries varies from one case to another. The Moldavian case is considered relatively successful. The results from Lithuania are especially worrisome, since the majority of female SME owners reported making insufficient earnings to cover their living expenses, suggesting that many of these enterprises are operating close to the margin of economic viability. In the Ukraine, the reported performance of women-owned enterprises is significantly better than in Lithuania. There is a lack of performance assessment in case study of Canada, which is emphasizing the importance of success for female entrepreneurs rather than using quantitative methods to assess profitability.

With regard to the factors hindering women from starting-up and developing their businesses, the results of the study are consistent with the theoretical background on female entrepreneurship, cited in the beginning of the paper. In this way, one of the biggest challenges encountered by female entrepreneurs regards acquisition and mobilization of start-up resources and the following hardship of acquiring financial resources for development and growth. These facts have been confirmed by empirical data from the case studies carried out in both developed and developing economies (Canada and the Ukraine). The same issue partly explains why women operated enterprises are still so rare compared with men operated businesses.

The barriers faced by women entrepreneurs in transition countries, according to the case studies analysed, were mainly taxation system (Moldova, the Ukraine, Lithuania), legal system (Moldova and the Ukraine), followed by bureaucracy and corruption (Moldova), low purchasing power (Lithuania), etc. Regarding the same issue, in Canada the three most serious problems faced by female entrepreneurs in Sudbury were a "weak economy", followed closely by a "high business tax" and the "unavailability of skilled labor". In this way, women in both developed and developing economies were unsatisfied by taxation system in their economies. Other similarities identified were the hardship of rising financial capital (the Ukraine, Canada) and availability of skilled labour force (Moldova and Canada).

When performing the comparative analysis of the case studies in different countries, similarities and differences were identified. The main difference concerning female start-ups was connected to motivation reasons. In this way, in developed economy the motivation for owning a business is explained by intrinsic factors, while in transition economies women are opting for self-employment out of necessity. However, although many female entrepreneurs may be "necessity driven" when starting their businesses, this does not necessarily determine their subsequent development path, which may involve a recognition of entrepreneurial opportunities as external circumstances change, and business owners themselves grow in confidence, competences and ambition.

Considering all the cited benefits brought by female entrepreneurship, the authors suggest its promotion, all together with the improvement of business environment, especially in transition countries. 


\section{Conclusions}

The main focus of the paper has been to prove that the level of economic development of countries, in which female entrepreneurs start up their businesses, exercises a strong influence on three analyzed patterns: the kind of motivation to set up a business, the obstacles faced and the level of accomplishment (success) they reach.

As the results showed, the reasons for starting-up, performances and hardships encountered are similar for the group of transitional economies. However, the evidence from the developed economy proved different results in terms of the researched patterns. In this way, the authors conclude that the main goal of the present paper has been successfully achieved and its scientific importance and viability have been proved.

\section{References}

Aculai, E., Vinogradova, N., et al. (2008). How to be successful in an adverse business environment: Knitwear factory in Moldova. Bodmin, Cornwall: MPG Books Ltd.

Aidis, R., Welter, F. et al. (2005). Female entrepreneurship in transition economies: The case of Lithuania and Ukraine.

Aldrich, H. (1989). Networking among women entrepreneurs. In O. Hagan, C. Rivchun, \& D. Sexton (eds.), Women owned businesses. New York: Praeger.

Anderson, S., and Eswaran, M. (2009). What determines female autonomy? Evidence from Bangladesh. Journal of Development Economics, 90(2): 179-191.

Benzing, C., Chu, H.M., and Kara, O. (2009). Entrepreneurs in Turkey: A factor analysis of motivations, success factors, and problems. Journal of Small Business Management, 47, 1: 58-91.

Boden, R. J. Jr., and Nucci, A. R. (2000). On the survival prospect of men's and women's new business ventures. Journal of Business Venturing, 15(4): 347-372.

Brush, C. G. (1992). Research on women business owners: Past trends, a new perspective and future directions. Entrepreneurship theory and practice (summer). P. 5-30.

Carter, C., Henry, C., and Marlow, S. (2009). Exploring the impact of gender upon women's business ownership. International Small Business Journal, 2(27): 139-148.

Carlassare, E. (2000). Dotcom divas: E-Business insights from the visionary women founders of 20 net ventures. New York: McGraw-Hill.

Centre of Women's Business Research. (2005). Retrieved November 20, 2012 from http://www.entrepreneur.com/article/82018

Cliff, J. (1998). Does one size fit all? Exploring the relationship between attitudes towards growth, gender, and business size. Journal of Business Venturing, 13, 6: 523-542.

Ernst and Young. (2005). Retrieved November 20, 2012 from http://www.ey.com/DLResults?Query=[C ountryCode] $=$ LT $\sim[$ LanguageCode $]=e n \sim[$ T_Services $]=($ Services $\backslash$ Tax $)$

Fafchamps, M., and Quisumbing, A. R. (2005). Assets at marriage in rural Ethiopia. Journal of Development Economics, 77: 1-25.

Hisrich, R. D. (1989). Women entrepreneurs: Problems and prescriptions for success in the future. In O. Hagan, C. Rivchun, \& D. Sexton (eds.), Women owned businesses. New York: Praeger.

Hisrich, R.D., and Brush, C.G. (1985). Women and miniority entrepreneurs: A comparison analysis. In Frontiers of entrepreneurship research. Wellesley, MA: Babson College, p. 566-587.

Hisrich, R.D., and Brush, C.G. (1984). The women entrepreneur: Management skills and business problems. Journal of Small Business Management, 22(1): 30-37.

Horrell, S., and Krishnan, P. (2007). Poverty and productivity in female-headed households in Zimbabwe. Journal of Development Studies, 43(8): 1351-1380.

Johnson, S., and Storey, D. (1993). Male and female and their businesses. Women in business: Perspectives on women entrepreneurs. London: Routledge. 
Marlow, S., and Patton, D. (2005). All credit to men? Entrepreneurship, finance, and gender. Entrepreneurship Theory and Practice, $(29,6): 717-735$.

Marlow, S., and Strange, A. (1994). Women entrepreneurs - success by whose standards? Women in management: A developing presence. London: Routledge, p. 172-184.

Minniti, M., Allen, E., and Langowitz, N. (2006). The 2005 global entrepreneurship monitor special topic report: Women in entrepreneurship. Babson Park, MA: Center for Women Leadership, Babson College.

National Foundation for Women Business Owners. (2001). Entrepreneurial vision in action: Exploring growth among women-and-man owned firms. Washington DC: NFWBO.

Nichter, S., and Goldmark, L. (2009). Small firm growth in developing countries. World Development, 37(9): 1453-1464.

Organization for Economic Co-operation and Development (OECD). Retrieved November 20, 2012 from http://www.oecd.org/statistics/

Prowess Report. Retrieved November 20, 2012 from http://www.prowess.org.uk/publications.htm

Riding, A., and Swift, C. (1990). Women business owners and terms of credit: Some empirical findings of the Canadian experience. Journal of Business Venturing, 5(5): 327-340.

Robichaud, Y., Cachon, J., et al. (2010). Motives, success factors, and barriers among Canadian female entrepreneurs: The case of Greater Sudbury. Retrieved November 20, 2012 from http://entpracticereview.org/motives-success-factors-and-barriers-among-canadian-female-entrepreneursthe-case-of-greater-sudbury/

Watson, J. (2002). Comparing the performance of male- and female-controlled businesses: Relating outputs to inputs. Entrepreneurship Theory and Practice.

\title{
MOTERŲ VERSLUMO GAIRĖS: TEORINĖ LYGINAMOJI STUDIJA
}

\author{
Xenia ANDRIUTA \\ Moldovos ekonominių studijų akademija, Moldova \\ Jekaterina KARTAŠOVA \\ Mykolo Romerio universitetas, Lietuva
}

Santrauka. Šiame straipsnyje, atliekant teorinị tyrimą, paremtą skirtingų šalių moterų verslumo studijomis, siekiama išryškinti moterų verslumo svarbą. Pagrindinis dėmesys nukreiptas ị svarbiausius motyvus, veiklos aspektus ir kliūtis, kurios būdingos moterims, pradedančioms nuosavą verslą skirtingomis geografinèmis ir ekonominemis sąlygomis (t. y. palyginti, kaip sąlygos pradèti verslą skiriasi išsivysčiusiose ir besivystančiose šalyse). Kadangi moterų verslininkių procentas yra mažesnis nei vyrų, straipsnyje siekiama paaiškinti ši polinkị ir išskirti pagrindinius suvaržymus, su kuriais moterys susiduria kurdamos ir plètodamos verslą. Pateiktais pavyzdžiais, taikant lyginamąją duomenų analizę, siekiama palyginti moterų verslumą skirtingose šalyse. Autorès daro apibendrinančią išvadą, kad moterų verslumo modeliai skirtingose šalyse yra nevienodi, ir siūlo taikyti skirtingus moterų verslumo skatinimo būdus.

Reikšminiai žodžiai: verslumas, moterys, verslo kūrimas, verslo skatinimas. 